\title{
Study of the Socio-Economic Status and Consumption Pattern of Green Leafy Vegetables among Selected of Farm Women
}

\author{
A. Mariammal $^{1}$, G. Hemalatha ${ }^{1 *}$, R. Saravanakumar ${ }^{2}$, P.P. Murugan ${ }^{3}$ and A. Beaulah ${ }^{4}$ \\ ${ }^{1}$ Department of Food Science and Nutrition, Tamil Nadu Agricultural University, India \\ ${ }^{2}$ Department of Apparel Designing and Fashion Technology, Tamil Nadu Agricultural \\ University, India \\ ${ }^{3}$ Department of Agricultural Extension, Tamil Nadu Agricultural University, India \\ ${ }^{4}$ Department of Horticulture, Tamil Nadu Agricultural University, India
}

*Corresponding author

\section{A B S T R A C T}

The study aimed to assess the socio-economic status and consumption pattern of green leafy vegetables among selected farm women (22 to 30

Keywords

Socio-economic, Farm women, Food expenditure,

Nutrition education

Article Info

Accepted:

10 July 2019

Available Online:

10 August 2019

years) belonging to Ayyur village of Alanganallur Block of Madurai

District in Tamil Nadu state by direct interview method. A well-structured questionnaire was formulated and used to elicit the information from 100 respondents. The data revealed that 31.00 per cent of the respondents had middle school education. Nearly 99 percentage of the subjects were married and most of the farm women were living in nuclear type of family (65\%) and 24 per cent of the respondents ate green leafy vegetables once in a week. The poor socio-economic conditions were found to have a significant effect on the health and nutritional status of the respondents which was also associated with poor intake of green leafy vegetables. Hence, nutrition education programs was imparted to create awareness and increase the consumption of micronutrient rich, low cost green leafy vegetables to improve nutrient intake and for better health.

\section{Introduction}

Micronutrient deficiency with reference to iron, iodine and vitamin $\mathrm{A}$ is a major health problem in the country. Also, referred to as 'Hidden Hunger' it affects the human health with a large portion of the population suffering from malnutrition. According to the
Food and Agriculture Organization report on the State of Food Security and Nutrition in the World, it is estimated that 190.7 million 14.5 per cent people were undernourished in India during 2014 to 2016 (FAO, 2018). In India, around 0.5 per cent of total deaths in 2016 were contributed by nutritional deficiencies (India State-Level Disease Burden Initiative 
Collaborators, 2017). Due to low socioeconomic status and household food insecurity, low intake of optimal diet and poor hygiene practices along with infection and infestation, superimposed by poor knowledge of micronutrient rich foods, improper diet (due to poverty, ignorance, low agricultural productivity, and cultural factors),poor intake of animal sources of vitamin $A$ and it precursor rich ( $\beta$-carotene) plant foods like green leafy vegetables, especially by households with severe food insecurity are the major contributors to micronutrient deficiencies.

Micronutrient deficiency conditions also relate to many chronic diseases, such as osteoporosis, osteomalacia, thyroid deficiency, colorectal cancer and cardiovascular diseases. Micronutrient deficiencies are not always clinically apparent or dependent on food supply and consumption patterns. They are associated with physiologic effects that can be life-threatening or more commonly damaging to optimal health and functioning. Iron deficiency is the most prevalent nutrition problem in the world.

Phenolics are the largest group of phytochemicals that account for most of the antioxidant activity in plants or plant products (Sulaiman, 2013). Green leafy vegetables are rich sources of micronutrients like iron, $\beta$ carotene and phytochemicals and are locally available, low cost and largely underutilized and needs to be promoted to provide the essential nutrients and to enhance immunity.

Health of women is directly related to the well-being of the entire family. Women with poor health and nutrition are more likely to give birth to unhealthy babies. While malnutrition is prevalent among all segments of the population, poor nutrition among women is much more as it begins at infancy and continues throughout their life. The women affected by malnutrition suffer from deficiencies of different nutrients. Malnutrition among women particularly iron deficiency anemia, calcium deficiency and vitamin A deficiency is are serious nutritional problems in India and in many other developing countries resulting in various consequences. Undernourished women are often physically weak and unable to perform income generating activities and household work to their full potential which creates worse effects that extends through generations and lead to economic losses for both the family and country. Malnutrition disempowers women by causing or aggravating infection, illness, lowering educational attainment and diminishing livelihood skills and drains family savings (Alam et al., 2010).

Women become malnourished because of inadequate nutritional knowledge due to lack of education which leads to nutritional deficiencies and detrimental effects on health, household food insecurity and illness. Proper nutritional knowledge of farm women is a big concern for their daily livelihood. The diet of rural family is deficient in energy, protein and micronutrients due to lack of proper consciousness about nutritional value of foods. The typical diet is predominantly rice based with no appropriate intake of protective foods such as green leafy vegetables.

Consequently, women do not eat enough protective foods to meet the energy and micronutrient needs during pregnancy when these needs are greatest (Rahman and Nasrin, 2008). As a result, maternal malnutrition is a chronic problem in rural areas of Tamil Nadu.

Hence, to reduce nutritional problems it is essential to impart intervention strategies to address issues such as lack of nutritional knowledge and increase the consumption of protective foods such as green leafy vegetables. Hence, the present study focuses 
on assessing the socio economic status of the farm women and consumption trend of protective foods with particular reference to green leafy vegetables.

\section{Materials and Methods}

\section{Selection of the study area}

The Ayyur village of Alanganallur Block of Madurai District with a population of 3426 was selected as the study area, since the main occupation of the villagers was agriculture and in view of the convenience and co-operation extended by the villagers. Preliminary survey revealed that the most of the population belonged to the low-income group and the village women were engaged in agricultural activities.

\section{Selection of subjects: - Sample selection and size}

The investigation was performed on 100 farm women selected randomly in the age group of 22-30 years with family income (<Rs.75, 000), who were willing to participate in the study were taken from study area.

\section{Design of questionnaire}

A detailed schedule was formulated using a specially designed socio-economic questionnaire to collect information on the socio-economic (age, type of family, size of family, marital status, occupation, income, debts and education), household expenditure pattern and consumption of green leafy vegetables of the selected subjects.

\section{Pilot survey}

A pilot survey was conducted to determine the feasibility of the study and validity of the questionnaire. The pilot study was conducted on ten per cent of the sample size.

\section{Conduct of survey}

The female farm women were interviewed to collect information randomly on socioeconomic status and consumption of green leafy vegetables. A well-structured questionnaire was formulated and used to elicit the information from 100 respondents.

\section{Statistical analysis}

The data was quantified, classified and tabulated and expressed in frequencies percentages and standard deviation was carried out.

\section{Results and Discussion}

The data regarding socio-economic status, household expenditure and consumption pattern of green leafy vegetables are presented in tables 1 to 4 and discussed herein.

\section{Socio-economic profile of the farm women}

Age

Socio-economic characteristics of farm women revealed from the Table 1 that one hundred respondents of selected subjects belonging to the young age group between 22 to 30 years were vulnerable to develop micronutrient deficiency and perceived agriculture as their main occupation.

\section{Education}

Regarding education level of the farm women, 28 per cent were illiterates followed by 15 per cent who had primary school education, 31 per cent with middle school education, 25 per cent of respondents had studied up to high school and only one per cent were graduates. Most of the farm women were illiterates owing to the then poor educational facilities available at the village level. 
Table.1 Socio-economic profile of the farm women $(n=100)$

\begin{tabular}{|c|c|c|}
\hline Characters & Number & Per cent \\
\hline \multicolumn{3}{|l|}{ Age } \\
\hline 22 to 30 years & 100 & 100 \\
\hline \multicolumn{3}{|l|}{ Marital status } \\
\hline Married & 99 & 99.00 \\
\hline Unmarried & 1 & 1.00 \\
\hline \multicolumn{3}{|l|}{ Type of family } \\
\hline Joint family & 35 & 35.00 \\
\hline Nuclear family & 65 & 65.00 \\
\hline \multicolumn{3}{|l|}{ Size of family } \\
\hline Small (1 to 3) & 21 & 21.00 \\
\hline Medium (4 to 6) & 72 & 72.00 \\
\hline Large (>6) & 7 & 7.00 \\
\hline \multicolumn{3}{|l|}{ Education } \\
\hline Illiterate & 28 & 28.00 \\
\hline Primary school & 15 & 15.00 \\
\hline Middle school & 31 & 31.00 \\
\hline High school & 25 & 25.00 \\
\hline Graduation & 1 & 1.00 \\
\hline \multicolumn{3}{|c|}{ Total income of the family (Annual) } \\
\hline$<75,000$ & 100 & 100 \\
\hline \multicolumn{3}{|l|}{ Occupation (Farm women) } \\
\hline Daily earners & 47 & 47 \\
\hline Agriculture (land holding) & 53 & 53 \\
\hline \multicolumn{3}{|l|}{ Debts } \\
\hline Agricultural loan & 0 & 0 \\
\hline Housing loan & 0 & 0 \\
\hline Educational loan & 0 & 0 \\
\hline Other (L\&T loan) & 34 & 34.00 \\
\hline
\end{tabular}

Table.2 Household expenditure of the farm women

\begin{tabular}{|c|l|c|c|}
\hline Sl. No & \multicolumn{1}{|c|}{ Particular } & $\begin{array}{c}\text { Average expenditure per } \\
\text { month (in Rs) }\end{array}$ & $\begin{array}{c}\text { Standard } \\
\text { deviation }\end{array}$ \\
\hline $\mathbf{1}$ & Food & 2046 & 464.58 \\
\hline $\mathbf{2}$ & Clothing & 85 & 192.99 \\
\hline $\mathbf{3}$ & Education & 423 & 688.55 \\
\hline $\mathbf{4}$ & Household equipment, furniture etc., & 9 & 63.71 \\
\hline $\mathbf{5}$ & Health & 755 & 277.93 \\
\hline $\mathbf{6}$ & Transport & 304 & 172.28 \\
\hline $\mathbf{7}$ & Fuel and electricity & 834 & 131.21 \\
\hline $\mathbf{8}$ & Communication & 254 & 116.70 \\
\hline $\mathbf{9}$ & Recreation and culture & 756 & 420.51 \\
\hline $\mathbf{1 0}$ & Savings & 0 & 0 \\
\hline $\mathbf{1 1}$ & Restaurants and hotels & 1 & 10 \\
\hline $\mathbf{1 2}$ & Entertainment & 2 & 14.07 \\
\hline $\mathbf{1 3}$ & Miscellaneous goods and services & 5 & 50.00 \\
\hline $\mathbf{1 4}$ & Routine household maintenance & 0 & 0 \\
\hline & & $\mathbf{5 4 7 4}$ & 2602.57 \\
\hline
\end{tabular}


Table.3 Frequency of food consumption pattern by farm women

\begin{tabular}{|l|c|c|c|c|c|c|}
\hline \multirow{2}{*}{$\begin{array}{l}\text { Green leafy } \\
\text { vegetables }\end{array}$} & \multicolumn{3}{|c|}{$\begin{array}{c}\text { Consumption } \\
\text { Purchase/Source of } \\
\text { food items }\end{array}$} \\
\cline { 2 - 7 } & Daily & $\begin{array}{c}\text { Once } \\
\text { week }\end{array}$ & $\begin{array}{c}\text { Once in a } \\
\text { month }\end{array}$ & Seasonal & $\begin{array}{c}\text { Own } \\
\text { produce }\end{array}$ & $\begin{array}{c}\text { Local } \\
\text { store }\end{array}$ \\
\hline Agathi leaves & 0 & 17 & 33 & 50 & 6 & 94 \\
\hline Chekkurmanis & 0 & 23 & 35 & 42 & 4 & 96 \\
\hline $\begin{array}{l}\text { Drumstick } \\
\text { leaves }\end{array}$ & 0 & 49 & 37 & 14 & 21 & 79 \\
\hline $\begin{array}{l}\text { Fenugreek } \\
\text { leaves }\end{array}$ & 0 & 39 & 51 & 37 & 2 & 98 \\
\hline Onion leaves & 0 & 9 & 24 & 67 & 8 & 92 \\
\hline $\begin{array}{l}\text { Manathakkali } \\
\text { leaves }\end{array}$ & 0 & 15 & 24 & 49 & 9 & 91 \\
\hline Mint & 0 & 19 & 36 & 42 & 5 & 95 \\
\hline Pasalai leaves & 0 & 6 & 39 & 70 & 1 & 99 \\
\hline Paruppukeerai & 0 & 23 & 24 & 50 & 12 & 88 \\
\hline Ponnananni & 0 & 27 & 27 & 40 & 13 & 87 \\
\hline Arakeerai & 0 & 41 & 33 & 20 & 11 & 89 \\
\hline Thandukeerai & 0 & 44 & 38 & 18 & 8 & 92 \\
\hline Sirukeerai & 0 & 32 & 35 & 33 & 4 & 96 \\
\hline Tree lettuce & 0 & 4 & 6 & 90 & 0 & 0 \\
\hline $\begin{array}{l}\text { Chakaravarthy } \\
\text { keerai }\end{array}$ & 0 & 12 & 8 & 80 & 0 & 100 \\
\hline & & & & & & \\
\hline
\end{tabular}

Table.4 Consumption pattern of green leafy vegetables

\begin{tabular}{|c|l|c|}
\hline Sl. No & \multicolumn{1}{|c|}{ Parameters } & $\begin{array}{c}\text { Women N= 100 } \\
(\mathbf{\%})\end{array}$ \\
\hline $\mathbf{1}$ & Daily & 0 \\
\hline $\mathbf{2}$ & Once a week & 24 \\
\hline $\mathbf{3}$ & Monthly once & 30 \\
\hline $\mathbf{4}$ & Seasonal & 46 \\
\hline
\end{tabular}

The finding is in line with the findings of Nagabhushanam and Nanjaiyan (1998) who reported that 28.30 per cent of farm women were illiterates.

\section{Marital status and type of family}

Majority of the subjects (99\%) were married, whereas, 1 per cent of farm women were unmarried. Nuclear family system was more prevalent among the farm women and most of the farm women were living as nuclear family $(65 \%)$ and the rest were belonged to the joint family type (35\%).

The farm women opined that the young and the middle aged people wished to lead an independent life which might be the reason for more number of nuclear families. The finding is in line with the findings of 
Yadavand Grover, (2012) who reported that 68 per cent of farm women belonged to nuclear type of families.

\section{Size of the family}

It was observed that majority $(72 \%)$ of the farm women belonged to the medium size family with 4 to 6 members followed by 21 per cent with small size family (1-3 members) and 7 per cent had large family (more than 6 members). The farm women expressed that they could lead better and comfortable life with small family size.

\section{Occupation}

From Table 1 it is clear that out of one hundred low socio economic $(>75,000)$ farm women, the majority $(47 \%)$ of the farm women were working as daily earners and remaining 53 per cent of women were involved in agriculture activities having own land. This observation was in concurrence with the findings of Krushna et al., (2017).

\section{Household expenditure pattern}

The data pertaining to the total income spent per month on food and non-food items are shown in Table 2. Higher expenditure on food items was observed in the study area. This was followed by expenditure on educating their children, purchase of clothes, household equipment and furniture, for routine household maintenance, health and transport, fuel and electricity, communication, recreation and culture, to go to restaurants and hotels, for entertainment, purchase of miscellaneous items and other services.

\section{Frequency of food consumption pattern by farm women}

Frequency of green leafy vegetables of farm women is presented in Table 3 present study revealed that it was found that more than 40 per cent of the women consume fenugreek leaves, arakeerai, thandukeerai on once in a week followed by once in a month. Only a few percent of the respondents opined that they consume tree lettuce, manathakkali leaves, pasalaikeerai once in a week followed by seasonal. The source of purchase at green leafy vegetables of the present study indicated that majority of the farm women purchase through local store followed by their own production.

\section{Consumption pattern of green leafy vegetables}

Consumption pattern of green leafy vegetables of farm women is presented in Table 4. The result obtained indicate that the consumption of different underutilized green leafy vegetables among the respondents was varied, with 30 percent of women consuming green leafy vegetables on a monthly basis, $24 \%$ of women once in a week, 46 per cent of women consuming seasonal only and whereas no women were found to consume green leafy vegetables on a daily basis. The reasons cited for poor consumption of the greens were due to non-availability and lack of awareness. The findings are in line with Joglekar et al., (2014) and Krishnendu and Prasannakumari (2015).

\section{Nutrition education through Information, Education and Communication (IEC)}

Nutrition education was conducted by using the information, education and communication (lecture, chart, folder, exhibition and training) model to make people aware about the nutritional significance of underutilized green leafy vegetables and to increase their consumption rate. So the nutrition education was given to farm women regarding the importance of nutrition, well balanced diet, calcium and iron rich foods, 
breakfast and exercise. Diet in farm women is very crucial because it influences the future nutritional status. So it is important to conduct awareness programmes on food choices and nutritional requirements on a regular basis especially among low income groups. Greger and Divilabiss (1999) have reported in their study that the nutrition education programme was reached the real beneficiaries as most of the Indian women and girl's diet is lacking in many nutrients and having low haemoglobin levels.

The present study concludes that the socioeconomic factors which influence the knowledge of rural women towards nutrition and health. The majority of the selected subjects belong to the middle school (31) followed by illiterate (28\%). Regarding the type of family, 65 per cent of the subjects belonged to nuclear family, the rest lived in joint family. The poor socio-economic status associated with poor intake of green leafy vegetables. No women were found to consume green leafy vegetables on a daily basis. The reasons cited for poor consumption of the greens were due to non-availability and lack of awareness. Arranging nutrition education programme through IEC activity was very effective and to create awareness and increase the consumption of micronutrient rich, low cost green leafy vegetables to improve nutrient intake and for better health.

\section{References}

Alam, et al., 2010. Nutritional status, dietary intake, and relevant knowledge of adolescent girls in rural Bangladesh. J. Health Popul Nutr, 28(1): 86-94.

Devaki, et al., 2015. Socio-economic profile of livestock farm women of Thiruvallur District, Tamil Nadu. International Journal of Science, Environment and Technology, 4(5): 1322- 1329.
FAO, IFAD, UNICEF, WFP and WHO, 2018. The State of Food Security and Nutrition in the World. Building resilience for peace and food security. Available from: $h t t p: / / w w w$. fao.org/3/aI7695e.

Greger, J. L., and Divilabiss L, 1999. Nutrition Education: Linking search, theory and practice, Jones and Bartlett. Indian Journal of Ecology of Food and Nutrition, 4: 213.

India State-Level Disease Burden Initiative Collaborators, 2017. Nations within a nation: Variations in epidemiological transition across the states of India, 1990-2016 in the Global Burden of Disease Study, 390: 2437-60.

Joglekar, et al., 2014. Awareness knowledge and attitude towards green leafy vegetables among urban women. Stud Home Com Sci, 8(2-3): 75-79.

Krishnendu, R., and Prasannakumari, B. 2015. Consumption Pattern of Green Leafy Vegetables by Rural women in District Thiruvananthapuram. J Krishi Vigyan, 3:9-13.

Nagabhushanam, K., and Nanjaiyan, K. 1998. Perceived opinion of trained farm women on institutional training. J. Ext. Edn., 9(3): 2120-2123.

Saghir, et al., 2005. An analysis of nutritional status of farm women in Punjab: A case study of tehsil Fateh Jung. Pak. J. Agri. Sci., 42(34): 83-88.

Sathyanarayan, et al., 2010. Socioeconomic status of livestock farmers of Narasapura village - A benchmark analysis. Veterinary World, 3: 215-218.

Satyanarayan, K., and Jagadeeswary, V., 2010. A study on knowledge and adoption behaviour of livestock farmers. Indian Journal of Animal Research, 44: 100-106.

Srivastava, S. and Singh, B., 2014. Understanding nutritional situation of farm women in rural arid areas of 
Rajasthan: A case study. J. Agr. and Life Sci, 1(2): 17-20.

Sulaiman, et al., 2013. Chromatographic studies and in vitro screening for acetyl cholinesterase inhibition and antioxidant activity of three Acacia species from South India, Analytical Chemistry Letters, 3(2): 111-118.
Participation of farm women in animal husbandry in Anand district of Gujarat., J. Community Mobilization and Sustainable Dev., 6(2): 117-121. Yadav, P. K., and Grover, I. 2012. Gender Analysis of Constraints Faced By Dairy Cooperative Society Members. Indian Res. J. Ext. Edu, 12 (2): 48-54.

Upadhyay, S. and Desai, C.P., 2011.

\section{How to cite this article:}

Mariammal, A., G. Hemalatha, R. Saravanakumar, P.P. Murugan and Beaulah, A. 2019. Study of the Socio-Economic Status and Consumption Pattern of Green Leafy Vegetables among Selected of Farm Women. Int.J.Curr.Microbiol.App.Sci. 8(08): 1190-1197. doi: https://doi.org/10.20546/ijcmas.2019.808.140 